\title{
'We Should Tax Sex Workers to Fund Subsidies for Families': Shifting Affective Registers and Enduring (Sexual) Norms in the Italian Northern League's Approach to Prostitution
}

\author{
Isabel Crowhurst* \\ Department of Sociology, University of Essex
}

This paper explores changes in the emotional and affective repertoires mobilized by the Northern League, a longstanding and successful radical right-wing populist party in Italy, to justify its recent prostitution policy proposal. Having dispensed to a large extent with the punitive and fearful rhetoric against migrant prostitution that characterized its previous campaigns, under its new leader the Northern League has been calling for the regulation of prostitution and for its profitable taxation. A façade of knowing authority on the complex issue of prostitution governance is established and asserted by the party leadership and citizens are encouraged to think and feel differently about sex workers, now identified as profitable human capital. The measures proposed, I suggest, far from being non-moralistic and ideologically neutral, as they are presented, reinforce a well-established, emotively appealing and normative dichotomy between potentially dangerous individuals in need of surveillance and the wholesome family, cornerstone of the nation in need of economic assistance to reproduce and thrive.

Keywords: emotional politics; governing through affect; taxation of prostitution; prostitution policy; sexual norms.

\section{Introduction}

Prostitution evokes strong emotional reactions, and public debates surrounding its governance are often emotionally charged to an extent that 'goes beyond the emotional investment that characterizes all public policy' (Wagenaar and Altink 2012, p. 284). The dominant emotions displayed and mobilized within political discussions of the issue include pity, sympathy, compassion, anger, fear, disgust, and shame, which are frequently combined despite their incongruence (Bjønness 2012; Wagenaar 2018; Wagenaar et al. 2017). Italy provides a compelling example of the intensity and persistence of such complexity in the country's 'never ending debates' (Danna 2004) on the issue. Since the passing of the 1958 prostitution law ${ }^{1}$ numerous proposals have been submitted to Parliament to replace it, and alternative approaches to the regulation of prostitution have been discussed in various public and political arenas, rarely in a dispassionate manner.

*icrow@essex.ac.uk 
With a focus on the Italian context, this paper explores changes in the emotional and affective repertoires mobilized by the Northern League, a longstanding and successful radical right-wing populist party (Betz 1994) in Italy, to justify the new measures it proposes for the economically profitable regulation of prostitution. My interest in these developments emerges from an ongoing project on the taxation of prostitution, an aspect that is often overlooked in studies on the governance of commercial sex, despite having a notable impact on the economic and sexual citizenship of sex workers (Crowhurst 2019). Here, I am particularly interested in making sense of the centrality that the Northern League has ascribed to the taxation of prostitution in its recent political campaigns and the approach developed to justify it. Having dispensed to a large extent with the punitive and fearful rhetoric against migrant prostitution characterizing its previous campaigns, the Northern League has more recently been calling for the strict regulation of prostitution and its taxation. The new measures proposed are presented as commonsensical and non-moralistic, entailing a shift away from the fear, disgust, shame and blame that both historically and still today are attached to and adopted in political campaigns against prostitution. Citizens are thus encouraged to think and feel differently about sex workers, now presented as profitable human capital. Such an operation of emotional management is rendered conceivable and tolerable to the public through evoking the need for the country to follow in the steps of the most civilized nations, and to ensure the wellbeing of the family. The party's new leader, Matteo Salvini, claims that by abandoning 'moral judgements' it will be possible to profit from this longstanding stigmatized activity and to redirect funds extracted from its taxation to provide free childcare and other state support to economically struggling Italian families. A façade of knowing authority on the complex issue of prostitution governance is presented, facilitated by ignoring the voices of sex workers and their concerns for the negative impact the new policy would have on them. The measures proposed, I suggest, far from being rational and ideologically neutral, as they are presented, reinforce an emotively appealing and normative dichotomy between potentially dangerous sexual practices and individuals in need of surveillance, and the wholesome family, cornerstone of the nation in need of economic assistance to reproduce and thrive.

\section{Emotional Politics}

Analysis of the issues outlined above draws on the expanding inter-disciplinary literature that looks at emotions as constitutive of the workings of government and policy (Jupp et al. 2017) 
and at power and emotions as 'conceptual twins' to be treated together (Heaney 2011). In this ontological terrain emotions are not considered to be psychological states, but economic, social and cultural practices that 'circulate and are distributed across a social as well as psychic field' (Ahmed 2004, p. 120). It is through their circulation, mobilization and representation that emotions assume economic and political value, for example by being put to work to rally, influence and govern the emotional states of citizens. Indeed, citizenship itself is constructed around 'the recognition and encouragement of emotions' (Johnson 2010, p. 496), or what is referred to as 'affective citizenship' (Jones 2005; Johnson 2010). Crucially, instead of assuming that technologies of governance and related constructions of citizenship and belonging are shaped around the reasoned expression, deployment and management of clearly defined emotions, this body of work looks at how governance practices are embedded in and sustained by emotional complexity and incoherence (D'Aoust 2014). In other words, affective governance is viewed as comprising an assemblage of often contrasting emotional strategies, some punitive and fear-invoking, others compassionate and aimed at fostering relationships and engagements, and yet others that claim to be practical, merely technical and therefore affectively neutral. This complex emotional orchestration reflects the multi-layered composition and conflicting interests of political actors and the state, itself 'an assemblage of discourses, practices, projects and technologies, all traversed by competing political forces and political projects' (Newman 2017, p. 23).

Janet Newman's (2017) analysis of the competing and loosely linked emotional articulations at the heart of contemporary austerity politics in England provides a sharp analysis of the ambivalent and unstable use of emotions in governance. Newman identifies three interlinked 'politics' underpinning austerity measures, each justified and sustained through contrasting emotional registers. Firstly, a politics of rationality, driven by technical competence and aimed at ensuring the economy's wellbeing. Hunter (2014) characterises approaches similar to this as depoliticized neoliberal governance, a 'nonpolitics' where unavoidable technical necessity is presented as a way of being reasonable, to promote 'universally desirable forms of economic expansion and democratic government around the globe' (Duggan 2003, p. 10 as cited in Hunter 2014, p. 9). To sustain this vision, 'governments strive to summon up a public mood of sacrifice, forbearance, patience' (Newman 2017, p. 32). In this way, even what is presented as purely 'rational' governance is in fact embedded in and entails a set of affective dispositions demanded of citizens. Secondly, a politics of responsibility is encouraged which promotes a new moral economy whereby individuals are called upon to feel responsible for their wellbeing. In other words, as 
Pykett et al. (2017, p. 3) put it, emotionalized states and their governments are meant to roll back and govern less, 'renouncing the highly rationalised state bureaucracy in favour of personalised forms of self-government'. In this context citizens are called upon to become self-reliant entrepreneurial individuals (Berlant 2011) and to direct their affective efforts to being focussed, rational and reasonable and thus contributing more effectively and efficiently to the greater good. Thirdly, a politics of division and rage emerges which blatantly deploys the emotional registers of stigma, blame and shame against those who are identified as responsible for weakening the economy and social bonds, in an effort to 'bind 'ordinary', hard-working and responsible citizens into a hegemonic 'we' - whose feelings of attachment are strengthened by fear of the other' (Newman 2017, p. 31). This analysis of austerity's three-tiered politics reveals that the most obvious emotional deployment, that of rage, is coexistent with other emotional regimes, albeit being presented as rational and un-emotional. In this way a complex picture of affective entanglements, entailing at the same time rationality, responsibility and rage, is presented, closely allying with what the Italian case discussed in the next sections reveals.

Finally, putting emphasis on the multi-layered emotional complexity of governance and politics is particularly relevant in the analysis of right-wing populist parties such as the Italian Northern League. As a growing body of scholarship shows, the rhetoric of populist parties uses a highly emotionalized style which relies on anger, blame, fear, anxiety, and shame to frame issues at the core of its politics, including immigration, nationalism, identity, economic (in)security, and the family (see, for example, Caiani and Della Porta 2011; Demertziz 2006; Hameleers et al. 2017; Jagers and Walgrave 2007; Rico et al. 2017; Salmela and von Scheve 2017; Vasilopulou et al. 2014). But other affective deployments, perhaps less ostentatious and also less obviously emotion-driven, should also be taken into account in exploring how political actors make sense of and gain support for their, often conflicting, political positions and policies. So, while indeed, 'politicians engage in discourse and rhetoric to evoke emotional responses, for an 'us' and against an emotionally constructed 'them"' (Heaney 2013, p. 358), other equally 'visceral' affective registers, often disguised in claims of no-nonsensical and affectively neutral rationality, can play a conspicuous role in politics.

\section{Source Material}

This paper is based on analysis of two types of documentary sources: official party documents published by the Northern League during its lifetime, and messages posted on the 
Northern League’s (@LegaSalvini) and its current leader Matteo Salvini’s (@ matteosalvinimi) official Twitter accounts. Party documents include policy briefs and proposals issued by the Northern League relating to its approach to prostitution, as well as articles and reports on the same topic published in the official party's newspaper La Padania during its circulation between 1997 and 2014. As far as the decision to analyse the two aforementioned Twitter accounts is concerned, this needs to be understood in the current context which sees social media playing an increasingly important role in the ways politicians and their parties communicate. Studies show that in addition to traditional communication channels and mainstream media, social media has been used as a particularly powerful tool by populist political actors (Bartlett 2014; Bobba 2019; Kriesi 2014). In Italy Matteo Salvini has been a catalyst in changing the communication strategy of the Northern League which now relies predominantly on social media (Albertazzi et al. 2018; Bobba 2019). He is the most active Italian political leader on social media and has one of the highest number of fans (Albertazzi et al. 2018), as testified by his over 3.6 million likes on Facebook and more than 1 million followers on Twitter (as of June 2019). 'This helps him shape (and, indeed, dominate) national debates on issues concerning identity, immigration, and law and order, as the controversial remarks made via his SM [social media] accounts are immediately picked up by the press and television news' (Albertazzi et al. 2018, p. 7). Messages posted on Matteo Salvini's and the Northern League's Twitter and Facebook accounts are identical, and when a tweet is shorter than a Facebook post, due to the limited characters allowed by Twitter, a link to his Facebook page is added to the message. To avoid the collection of duplicate messages this study is based on Twitter posts only. Using Twitter's advanced search tools in the two accounts selected the keywords 'prostitution', 'Merlin' (the 'nickname' of the current prostitution law, see footnote 1), 'prostitute', 'prostitutes' and 'sex work' ${ }^{2}$ returned a total of 207 tweets covering the period since the accounts were opened, Matteo Salvini's in March 2011 and the Northern League's in February 2008, and until June 2019. Tweets, relevant linked material included in them (such as videos and articles in the press and on digital media), and official party documents were analysed thematically through a content analysis of the more and less explicit emotional and affective, visual and verbal messages and signifiers identified.

\section{The Northern League's Shifting Approach to Prostitution}

This section starts with a brief overview of the Northern League and its claims and demands over time. It then moves on to look at the approach taken by the party towards the regulation 
of prostitution until the early 2010s and the adoption of images of danger, invasion and threatening proximity underpinning it. Drawing on, but also moving away from these affective economies of fear (Ahmed 2004), since 2013 the new party leader's use of prostitution as a political issue reveals a marked rhetorical, affective and emotional shift, which is the focus of the analysis in the remaining parts of this article.

Founded in the 1980s with a strong ethno-regionalist focus, the Northern League is considered one of the most successful radical right-wing populist parties in Europe (Bobba 2019). After gaining electoral capital during Italy's major political crisis in the 1990s, it became the country's fourth largest party and formed part of various right-wing coalitions between 2001 and 2011 (Caneva 2014). Its popularity dwindled in the early 2010s following a series of scandals involving its historic leader Umberto Bossi, but after facing an uncertain fate it regained strength under Matteo Salvini who took control in 2013. At the general elections of 2018 the Northern League performed exceptionally well, gaining over 17 per cent of the national vote. In May 2018 it entered a coalition government for the fifth time in its history and Matteo Salvini was appointed Deputy Prime Minister and Minister of the Interior (Albertazzi et al. 2018).

Guided by the anti-elitist and anti-politician rhetoric of its founder, Umberto Bossi, and through his 'direct, simple, simplifying and often offensive' 'man of the people' communication style (Fremeaux and Alberatazzi 2002, p. 150), until the late 2000s the Northern League advocated for the independence of the northern regions from the corrupt centre of political power in Rome and the inefficient South. It also virulently attacked immigration, which it presented as a threat to the country's values and traditions and blamed for its socio-economic decline. With a similar 'no-nonsense' approach, Matteo Salvini has kept anti-immigration at the centre of the party's ethos, but replaced regionalism with nationalism - thus expanding its electorate across the country - and Rome with the EU as the people's enemy (Albertazzi et al. 2018). In line with other radical right-wing populist parties, the Northern League's official discourse has revolved around a commitment to defend the 'traditional' family from a variety of different threats. At different times during the course of the past two decades these have included: 'foreign men', often portrayed as dangerous rapists; the transition towards a multi-racial society, seen as a threat to the purity and homogeneity of the nation and the family; same-sex marriage and abortion, considered to be against the normative social and natural order; gender ideologies, viewed as dangerously destabilizing 'normal' sex roles (Akkerman 2015; Avanza 2010; Crowhurst 2012; Lega Nord 2018; Saitta and Piasecka 2006; Scrinzi 2017) and, until recently, street prostitution. 


\section{(Migrant) Street Prostitution as a Threat to the Nation and the Family}

Since the early 2000s the Northern League's political programs and manifestos have included proposals to reform the 1958 prostitution law which, as seen earlier, remains in place to this day despite being inadequate to addressing contemporary developments in commercial sex in the country. At the heart of the measures put forward over the years is a simplistic gendered and dichotomous understanding of prostitution as exercised by autonomous women in indoor premises and by coerced women in outdoor public spaces (Lega Nord 2002a). It is the latter, outdoor prostitution, that the party identifies as the most problematic and in need of immediate state intervention. The vast majority of those who practice it are migrant women whom the Northern League has not shied away from representing with racist and sexist stereotypes (Crowhurst 2007; 2012), and accused of: invading public spaces, scandalizing children with their scant attire, posing a sanitary risk for 'the client and his family', threatening 'love marriage' with their availability outside the home, and also attracting foreign criminals who exploit them and are thus able to accumulate wealth and expand their illegitimate businesses across the country (Boiocchi 2002; Lega Nord 2002a, 2002b, 2012;). With a view to addressing these multiple threats and to 'protect public safety, public health and to safeguard public morality' (Lega Nord 2002a, p. 2), in 2002 the Northern League submitted to Parliament a law proposal on 'prostitution, paedophilia, and pornography'. In introducing it Umberto Bossi emphatically stated,

An end to the rotten world that has been attacking the family is finally about to come.

We have now launched a campaign against [...] prostitution on the streets, which is often seen as alternative to one's wife outside the house. (Savoini, 2002 ${ }^{3}$ )

The law proposed to criminalize outdoor prostitution whilst allowing it in specific private buildings - referred to as Eros Centres. Thus, as Roberto Calderoli, the then Northern League's National Secretary reportedly stated, 'if someone has a real need to access it [prostitution], they should go to specific areas, far from the normal context of everyday life' (Boiocchi, 2002). In this way, he continued, not only would the practice cause less public disturbance, but 'we would avoid the shocking show that goes on in our streets at any hour of the day' (ibid.). The law proposal also introduced new stringent medical checks for sex workers and required their registration with the police. The taxation of prostitution was 
briefly mentioned in the proposal: 'fiscal measures are introduced to ensure that prostitutionrelated earnings are taxed and that prostitution is assimilated to other professional activities' (Lega Nord 2002a, p.4), although no further explanation was provided about how this would be implemented in practice.

Driving the need for the policy interventions spelled out in this law proposal was first and foremost the threat of migrant prostitution, its invasion of Italy's public places, and its attack on the country's values. Prostitution per se was not condemned, but rather approached as ineradicable and thus needing to be regulated to eliminate aspects of it that could not be tolerated, i.e. (migrant) street prostitution and the dangers that come with it. The consistent use of emotional language and images - threat, menace, invasion, children's purity under attack, slavery-like exploitation, foreign criminal rings - contributed to presenting a picture of urgency, of a need to intervene sooner rather than later to prevent a complete loss of control over public goods, spaces, and values. With this approach the Northern League asserted its power through the historically well-established construction and disciplining of dangerous 'foreign' bodies (Nagel 2003), claiming that it would protect the country from their physical and cultural occupation. However, in a rather contradictory manner, in addition to its commitment to get rid of 'foreign prostitutes' the law was also presented as having a humanitarian intent. The repressive and regulatory turn advocated, it was claimed, would put an end to sex trafficking, freeing exploited migrants forced to operate in outdoor prostitution (the same accused of invading public spaces), and as a result it would rid the country of the foreign criminals whose presence these 'trafficked victims' were blamed for (Lega Nord 2002a). This contemporaneously repressive and, allegedly, humanitarian intervention was described in belligerent terms as a battle and a fight that the Northern League had committed to embark upon to bring the 'oldest profession' under state control, to 'clean the streets', to put an end to prostitutes' criminal exploitation and related expansion of foreign criminality, and thus ultimately to defend the core of societal stability: the 'traditional Italian family'.

Neither the 2002 law proposal nor similar other bills that the Northern League supported and submitted in the 2000s ever became law. Nevertheless, prostitution, its containment and strict regulation through a law and order framework continued to form part of the policy commitments of the party, albeit becoming side-lined in the context of the national and economic crises of the decade. The taxation of prostitution remained listed in the changes advocated but was never given much attention in the publicity devoted to the issue. It was not until Matteo Salvini was elected new leader of the Northern League in 2013 that the regulation of prostitution returned as a salient policy issue in the party's political 
program, and the benefit of taxing prostitution became dominant in the political campaign launched to promote the new initiatives advocated.

\section{Making Economic and Political Capital out of Prostitution}

Whilst maintaining continuity with the Northern League's historical regulationist approach to prostitution, Matteo Salvini discarded proposals to create 'Eros centres' and geographically bounded red-light districts, which, he tweeted, 'don't make any sense', asserting that instead ‘we must repeal the Merlin Law, regulate and tax prostitution' (7/2/2015 @ matteosalvinimi). In the new campaigns spearheaded by Matteo Salvini the Northern League blames the anachronistic Merlin Law for having led to the expansion of street prostitution, and maintains that its repeal will bring various positive developments to the country: street prostitution and the social and spatial degradation that come with it will finally be eradicated as it is not possible to allow the trade of Women under the open sky' (30/05/2017 @ matteosalvinimi $\left.{ }^{4}\right)$; there will be a return to the strict control of indoor prostitution; public health will be protected; organised crime, trafficking and exploitation will be 'dealt with'; and order and safety will return 'to our cities' (Lega Nord 2014a). New fiscal measures put in place to tax prostitution will also allow to 'reduce or eliminate other taxes that burden citizens' (Lega Nord 2014a) and will bring much needed money into the state coffers $(28 / 3 / 2014 ; 12 / 5 / 2015$ @LegaSalvini).

What would a repeal of the Merlin Law entail in practice? Some hints are made to the re-opening of the so-called closed houses, the infamous state-regulated brothels that the law had abolished, but no further specifications on how the proposed changes will be achieved are provided, and the typology of organised prostitution that would be put in place remains unclear. The lack of details, however, has not stopped the Northern League from promoting its proposal. In 2013 Matteo Salvini announced his interest in calling for a referendum to repeal the Merlin Law. He tweeted, 'if the Northern League organised a popular referendum to repeal the MERLIN law, to TAX PROSTITUTION, take it away from the streets, regulate it, and gain a few billions, would you cast your vote?' (4/8/2013 @ matteosalvinimi). Following support for the idea, in 2014 the party's local offices organized 'gazebo days' during which the iconic Northern League's green gazebos were set up in the squares of many cities across the country to gather the 500,000 signatures needed to submit the request for a referendum. ${ }^{5}$ This extensively promoted initiative was successful but the signatures collected fell short of the quorum. A second round of equally widely publicized signature-collection 
'initiatives for the people', as they were referred to, was organised in 2015. This time enough signatures were collected, but after being submitted to the apposite court the request to call for a referendum did not move forward to the next approval stages and eventually ended in a stalemate. Despite not amounting to any change in policy, the widespread and visible local presence of the Northern League's gazebos and billboards to advertise the collection of signatures, coupled with social media publicity and media coverage, contributed to attracting political and public attention to the party's demands pertaining to prostitution, including the focus on taxation.

As Matteo Salvini's tweet cited above already indicated, since the first campaigns to repeal the current prostitution law the Northern League has placed emphasis on two key objectives: taxing prostitution and freeing 'the streets of our cities'. Three tweets are reproduced below as examples of the prominence given to both (Figure 1). On the left is a tweet posted on the Northern League's account. The text reads: 'Matteo Salvini: 'From 29/3 [29 $9^{\text {th }}$ March 2014] REFERENDUM to abolish the MERLIN law, regulate and TAX prostitution. Are you going to sign?', The same message is included in the image below the text, which shows a confident and expectant Matteo Salvini, a crossed 'Yes', in favour of the repeal of the law, and two pictures, one, supposedly of a sex worker soliciting on the street, and a second one of Euro banknotes, possibly symbolizing the financial profit that the taxation of prostitution would bring to the country (11/3/2014 @LegaSalvini). In the middle is a tweet posted on the Northern League's account calling for people to go and sign for the referendum: 'LET'S TAX PROSTITUTION: from tomorrow. Come and sign' (28/3/2014 @LegaSalvini). Below this text is a photograph of one of the billboards displayed during the 2014 referendum campaigns. With a green background, the traditional colour of the Northern League, the billboard's central message reads 'Let's tax prostitution' and next to it is the drawn silhouette of a sex worker soliciting on the streets near a lamppost (28/3/2014 @LegaSalvini). In the third tweet, on the right, Matteo Salvini writes: 'REGULATE and TAX prostitution as it is done in many other European countries, it's a fight for COMMONSENSE: let's free our streets and fight human traffickers. More safeguards, more health checks and more safety. LESS hypocrisy'. The tweet includes an image of Matteo Salvini holding one of the posters used in the 2015 referendum campaign. Next to the poster's message 'Let's free our streets and tax prostitution' is the same drawn silhouette of a street sex worker that appears on the billboard (16/1/2016 @ matteosalvinimi). What can be observed here is that while the call to 'clean the streets' has remained just as central as it was in the party's campaign in the 2000s, the prominence given to the taxation of prostitution and 
its benefits represents a new development - one that Matteo Salvini has energetically championed through the mobilization of different emotional and affective registers.
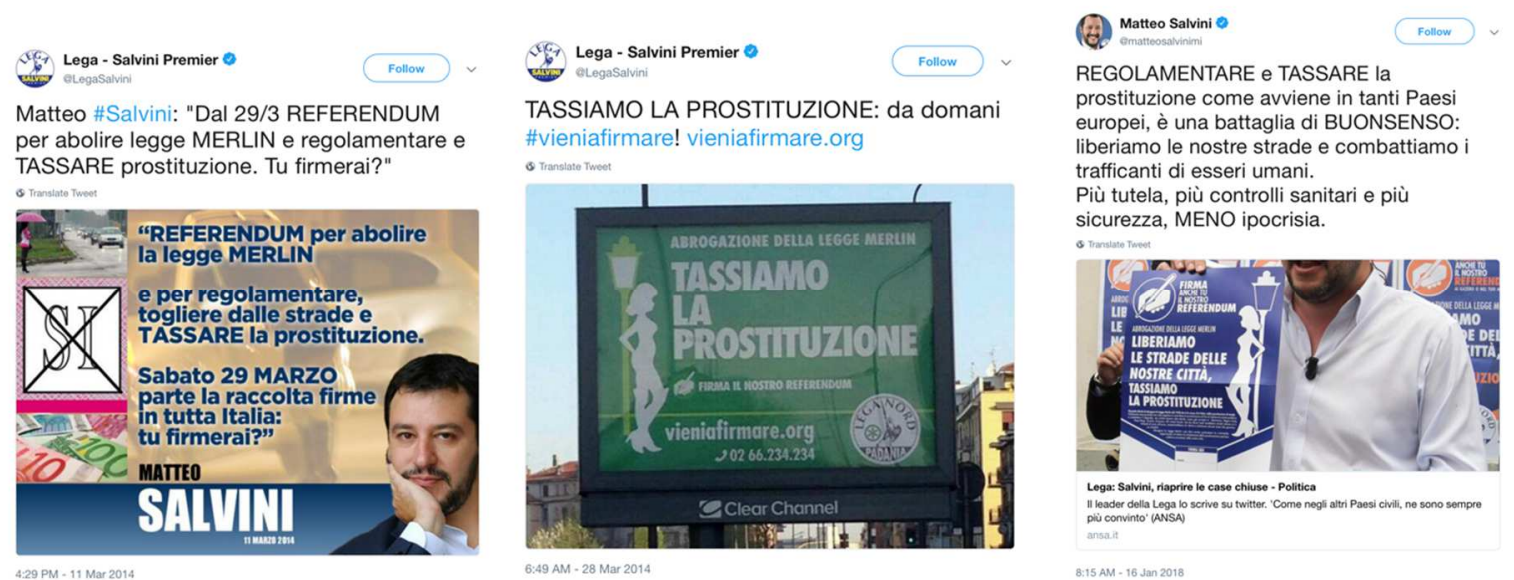

Figure 1: Three tweets on the Northern League's campaigns to repeal the Merlin Law

As discussed earlier, under Umberto Bossi's leadership the campaign to change the Merlin law and introduce a regulationist approach revolved around the threat that 'foreign prostitution' and its exploiters represented to the Italian nation and family. With the involvement of Matteo Salvini the deployment of the threatening and fearful images and messages associated with 'foreign prostitutes' has shifted. The silhouette used to symbolize street sex workers in the Northern League's most recent campaigns, as seen in figure 1 above, can be viewed as symbolic of this change: whilst the Northern League propaganda material had previously represented 'foreign prostitutes' as grotesquely sexualized and racialized and with a menacing and intimidating demeanour (Crowhurst 2012; Barcella 2018), here a slender street sex worker is unthreateningly awaiting clients, and by leaning against a lamppost she appears to take up little (public) space. The injurious presence which needs to be urgently eliminated is no longer that of street sex workers - who will be relocated and thus surveyed indoors once the Merlin law is repealed - but rather that of foreign traffickers and criminals. In a tweet Matteo Salvini claims that 'immigrants are responsible for $40 \%$ of the rapes and for 75\% of the crimes linked to prostitution' (15/2/2016 @ matteosalvinimi), and similar messages consistently emphasise the 'foreignness' of criminals exploiting prostitution, be it a 'gang of Rumanians and Albanians' (5/5/2017 @LegaSalvini); an 'ItaloRumanian gang' (19/06/2017 @LegaSalvini), an ‘Albanian gang' (6/12/2016 @LegaSalvini); extracommunitarians ${ }^{6}$ (22/6/2016 @LegaSalvini), the 'Nigerian Mafia' (25/02/2019 @ matteosalvinimi); or ‘foreigners' and 'foreign organised crime' responsible for 
drug and sex trafficking (15/3/2017 @LegaSalvini and 2/03/2019 @ matteosalvinimi). While violent criminal foreigners remain a target of the Northern League, in line with its core antiimmigration ethos, attacking 'street prostitutes' with the same vehemence as the 2000s campaigns would be incompatible with the new message being conveyed: that prostitution, when strictly regulated and taxed, will be good for the country. New emotional and affective dispositions are now relayed to and expected of the public: while foreign criminals should still be feared and the Northern League relied upon to prioritize the fight against them, the abjective emotional responses that have historically been displayed towards prostitution should be put to rest. Italian citizens are now invited to trust the party's leader's call to recast this historically stigmatized activity as an economically valuable resource that needs to be taken advantage of, particularly in the context of the country's ongoing economic crisis ${ }^{7}$. The feelings of fear, disgust, shame, and anger previously evoked towards migrant prostitution are now more explicitly directed at its 'foreign exploiters', and the family, previously presented a victim of prostitution is now its main beneficiary, as further discussed below.

'Do we need money?' (18/11/2014 @ matteosalvinimi), 'Are we short of cash?' (4/10/2012@matteosalvinimi) asks Matteo Salvini. As this is indeed the case, he tweets, Italy should legalize and tax prostitution, following in the footsteps of other European countries (18/11/2014; 4/10/2012 @ matteosalvinimi). The taxation of prostitution, he explains, 'is advantageous for all: more rights, more safety, more money for the state' (26/5/2015 @matteosalvinimi), although the amount of money that this will bring to the state remains unclear, and various tweets report figures progressively decreasing over time: from 'billions' (28/3/2014; 12/5/2015 @LegaSalvini), to four billions (Lega Nord 2013), to three billions (14/5/2015 @ matteosalvinimi), to two billions (30/5/2017; 18/1/2018 @ matteosalvinimi). Whatever their actual total, it is suggested that these funds, which could be collected if the Northern League were in power, ${ }^{8}$ will not only be beneficial for the nation at large, but they could provide much needed economic respite and infrastructural support in aid of the financially struggling Italian family. Within this understanding, if regulated strategically as envisioned by the Northern League, prostitution will become an invaluable resource that can: reduce burdensome taxes that unjustly weigh on most families' stretched finances, guarantee pensions for all, and make it possible to set up free childcare facilities. The possibility of investing in the latter is especially emphasized in the Northern League's campaigns to tax prostitution: 
'Free state nursery schools: they cost 2 billions, I refuse to think that we cannot do it. Let's tax prostitution' (20/07/2019 @ matteosalvinimi); 'Let's tax prostitution and we can help families with children who go to nursery schools’ (31/5/2016 @LegaSalvini); 'Prostitution, let's tax it and move it away from the streets. With that money we can provide children with free nursery schools like in France' (28/2/2015 @ matteosalvinimi); 'Free state nursery schools. The costs? They can be covered with the taxation of prostitution' (17/7/2014 @ matteosalvinimi); 'Free nursery schools across Italy: they would cost 2 billions, if we tax prostitution the state would gain 3 billions, what do you say?' (27/4/2014 @ matteosalvinimi).

In other messages the revenues collected through the taxation of prostitution are presented as part of the solution to the country's low natality rate:

'Europeans must get back to making BABIES, let's help them with free NURSERY SCHOOLS. The money can be taken from the taxation of prostitution' (29/3/2017 @ matteosalvinimi); and 'Birth rate in Italy is at its lowest. We should tax sex workers and use the revenues to fund subsidies for families' (4/2/2017 @ matteosalvinimi, original message in English ${ }^{9}$ ).

To enable these measures in favour of the family, it is claimed, it is necessary to recognize the very existence of the phenomenon of prostitution and to move beyond the moralisms that have created a stalemate in its governance - 'there is no point in pretending that prostitution does not exist' (16/4/2015 @ matteosalvinimi); 'I don't give moral judgements, but prostitution exists and needs to be regulated, taking it off the streets' (18/1/2015 @ matteosalvinimi). It is also stated that this approach is in the interest of sex workers themselves who will be 'better protected, safe and clean' (5/5/2015 @ matteosalvinimi). 'We want prostitutes to be subjected to medical checks and that they carry out their profession far from the streets, in safe areas, restricted by law. The repeal of the Merlin Law would mean more safety and more guarantees for those who carry out this activity' (Lega Nord 2014b). The management of prostitution to give 'safety and health guarantees to prostitutes and clients' (16/4/2015 @ matteosalvinimi) is presented as a 'fight for civilization' (15/6/2015 @ matteosalvinimi), one that 'other civilized countries' have already fought and won $(5 / 5 / 2015 ; 15 / 1 / 2018 @$ matteosalvinimi). Not to follow in their footsteps is viewed as a display of the incompetence and hypocrisy of the government, of 
other parties and of political leaders who are blamed for making hollow promises, all resulting in inaction:

'Renzi [the then premier of the country] should commit to taxing prostitution, otherwise his are all empty words' (24/3/2014 @ matteosalvinimi); 'Banning prostitution? A great hypocrisy. I am for its regulation and taxation, and its full legalisation' (4/2/2016 @ matteosalvinimi); ‘A state that makes money out of slot machines, alcohol and tobacco but does not accept prostitution is hypocritical' (16/4/2015@matteosalvinimi).

With a view to signalling a rupture with the government of the time, Matteo Salvini's rhetoric appears to be challenging the historical and 'hypocritical' association of prostitution with deviance, crime, immorality, social threat, and violence (Scoular 2015) which had also been an explicit part of his party's previous campaigns. In contrast to it and unlike his political opponents, he promises a ‘battle for commonsense' (16/01/2018 @matteosalvinimi) and an enlightened vision that moves beyond burdensome morals, offering guarantees to sex workers, and ultimately contributing to the common good. However, as I further elaborate in the following section, while it is presented as a judgement-free matter of technical competence to 'balance the books', the message underpinning the Northern League's position on prostitution evokes and reinforces well-established divisions between 'good' and 'bad' ways of being a (sexual) citizen that can hardly be viewed as enhancing, as it is claimed, sex workers' rights and working conditions.

\section{Shifting Affective Registers and Enduring (Sexual) Norms}

In the 2000s the Northern League did not deny or ignore that prostitution is an economic activity, indeed the taxation of prostitution was part of the party's political program from the beginning. Nevertheless, affective and emotional conventions of sexuality such as sexual shame, stigma, disgust (Irvine 2008) and a racialized politics of fear targeting unwanted and allegedly sexually dangerous migrants were deployed more prominently in conjunction with prostitution policy proposals in order to strengthen the party's image as the defender of the nation and of 'traditional' values, both under attack. In the 2010s the change in the party's leadership entailed a switch in the emotional regime employed to muster support for the party's position on the matter. With Matteo Salvini, the party makes an emphatic claim for 
the recognition of regulated indoor prostitution as part of the formal economy and promises that the nation will benefit greatly from the earmarking of prostitution-related taxation revenues for much needed public expenditures. This approach is presented, using Hunter's (2014) words previously cited, as an 'unavoidable technical necessity' that entails a 'nononsense' view of prostitution as a phenomenon that needs technical and concrete solutions. The affective register displayed by the party leader is no longer one of anger and aggressiveness, as had been the case with Umberto Bossi, but rather of control and rationality. Citizens are encouraged to trust these attributes and the party leader's vision and to abandon the historically-ingrained affective and emotional approaches that had cast prostitution exclusively as disgusting and fearful. This is a lot to ask. In order to summon up support for this new political approach, the trope of the threatening foreigner is not relinquished, although no longer central in the party's rhetoric. According to it, the streets still 'need to be cleaned', however the matter out place (Douglas 1966) to get rid of are no longer 'foreign prostitutes' but foreign criminals and gangs who exploit them. But it is another well-trodden emotional trope that gains prominence in the new campaign: the family, its wellbeing and survival.

The appeal to 'family feelings' is commonly used by politicians (Johnson 2010) and, as seen earlier, the protection of the family had been central in the previous Northern League campaign against outdoor prostitution. Matteo Salvini, however, shifts the relationship between prostitution and the family that had characterised previous campaigns. Now sex workers are presented as human capital, an untapped financial resource which is going to help the Italian family. To encourage citizens to detach themselves from anti-prostitution sentiments and to think more strategically and long-term about the issue, the wellbeing and future of the family and children serve to mobilize feelings of care and protection. Evoking anxieties and insecurities spurred by the economic crisis, the deficit and lack of public spending serves to reinforce support for the Northern League's rhetoric and citizens are asked to act and think responsibly about what is best for the country. Although not explicitly presented as such, a choice is put forth in the Northern League's campaigns: what is more important? Moralistic and ideological approaches to prostitution and visceral opposition to it that will bring no change, or, more practical, instrumental measures that will help the family? Choosing the former is portrayed as a betrayal of the country's interests, and a hypocritical position which is what current governmental leaders and politicians with a lack of vision and ambition continue to pursue. Choosing the latter will not only guarantee better futures to families and children, but it will also bring the country to a new level of civilization. Here the 
affective attachment of national pride is also mobilized with the promise of raising Italy to the level of other model countries. Like France, Italy will be able to provide free nursery schools to children, and similarly to what other 'civilized counties' have already done, regulating and taxing prostitution will bring multiple benefits to all, including sex workers.

Indeed, the new measures are presented as generous concessions to sex workers who will no longer be criminalized and whom good citizens are asked to tolerate in order to guarantee a better future to the country and enhance its reputation and exemplary role. By recognizing prostitution as a legitimate economic activity, and by being allowed to pay taxes, it is claimed that sex workers will learn the responsibilities that are already taken up by all other law-abiding citizens. They will enjoy taxpayer citizenship (Walsh 2018), they will be allowed to operate in enclosed, strictly policed and safe spaces, and will be subjected to regular medical checks. This will result, as Matteo Salvini tweeted, in having cleaner and safer sex workers with more guarantees.

Tolerance, however, as Brown (2006) posits, is not a practice of inclusion, but rather a posture of indulgence that enhances and sustains the 'Other's' abjection whilst reinforcing the superiority of, in this case, the magnanimous leader and the good, tolerating citizens. The emotionally powerful juxtaposition upon which the message of the Northern League and of its leader is based is value-laden and reinforces enduring hierarchies of 'good' and 'bad' citizens. On one hand we have families, the 'good' citizens who are unjustly struggling because of economic strains and political ineptitude and who need to be put in the conditions to procreate and thrive. On the other hand, at the outer limit of the 'charmed circle' (Rubin 1984) of 'good' citizens are sex workers who are now given a chance to contribute to the nation's wellbeing by providing the means to support ailing families. The conditions for this to take place is that the state takes full control of their bodies and sexual health, and that they are kept spatially circumscribed and policed. What is described as a progressive and civilized set of measures will give sex workers the right to pay taxes, the 'more rights' alluded to by Matteo Salvini, and it will also entail a return to the pre-Merlin Law regulationist system that took many years to get rid of. This forced sex workers to comply with regulations - such as registering with the police, undergoing biweekly vaginal checks, working in strictly surveyed state-brothels - that soon made them subject to a series of abuses, including police harassment, overcharging by doctors, difficulty in obtaining documents for marriage purposes, and being tarnished publicly as unrespectable, diseased and disordered (Gibson 1999). 
It is not the scope of this paper to evaluate the specificities of the proposal set forth by the Northern League nevertheless, it is worth noting that sex workers were never consulted in its development. Prostitution policy design should entail a thorough analysis of the complex phenomenon it aims to address in collaboration and consultation with experts in the field, including those who operate in the sex industry. Instead, it is often reduced to dogmatic claims and simplistic solutions that have electoral appeal but end up being impractical and often result in unforeseen and problematic effects (Wagenaar and Altink 2012). Unknowns, ambivalences and complexities - of which there are many in the sex industry - are viewed as political hindrances that should best be avoided. The more undoubting and assertive the authority with which prostitution policy measures are presented, partial or unrealistic as they may be, the stronger is the affective confidence and sense of power and control that the 'knowers' convey (Crowhurst 2017). Like his predecessor, Matteo Salvini has never shown any doubt over the best way for the country to manage prostitution. Through his display of confidence, ownership of the issue and a sense of control, and by ignoring the voices of sex workers and the multi-layered complexity of the sex industry he has been able to justify the shift in affective and emotional dispositions demanded of the electorate with a plan that he presented as the most reasonable and beneficial to the country.

\section{Conclusion}

This paper presented an example of the role of affects and emotions in making sense of prostitution and its governance. The focus on the Italian Northern League revealed a shift in the affective and emotional regimes relayed to and demanded of the population toward the phenomenon. This case, in line with the literature of emotional politics reviewed earlier, has shown the complex coexistence of multiple, contradictory emotions used to influence citizens' feelings. Similarly to what Newman (2017) had identified in her study, the Italian case emphasizes a turn to what is presented as technical and rational politics. However, far from it, multiple affective and emotional registers have been deployed to sustain it: from the ever-present fear of dangerous foreigners, to the need for citizens to take responsibility for the future of the nation, to feel differently about sex workers and to learn to tolerate the 'Other' within, to the promise of supposedly including sex workers and responsibilize them into serving for the country. Coupled with these affective and emotional mobilizations is Matteo Salvini's display of knowing authority, easily conveyed through social media, which enables to ignore the complexity of the phenomenon at hand and the voices of those whom he 
claims to want to provide with more rights. The vision of the future that is 'passed' as enlightened and progressive, however, is not too dissimilar from a Handmaid's Tail (Atwood 1986) scenario, where sex workers are kept in surveyed and strictly policed spaces, with their bodies regularly checked and inspected by others, in order to carry out their activity to save the nation and the family.

\section{Acknowledgements}

I would like to thank Caterina Fantacci for her support in collecting the data analysed and the Independent Social Research Foundation for supporting the research project 'Comparing the taxation of prostitution in Europe: experiences and negotiations with laws and fiscal arrangements' from which this article emerges.

\section{Notes on contributor}

Isabel Crowhurst is a Senior Lecturer is Sociology at the University of Essex, UK. Her research explores the intersection of sexual and economic citizenship in the governance and lived experiences of commercial sex, and the changing nature of intimate citizenship regimes in Europe.

\section{References}

Ahmed, S., 2004. Affective economies. Social Text, 22 (2), 117-139

Akkerman, T., 2015. Gender and the radical right in Western Europe: a comparative analysis of policy agendas. Patterns of Prejudice, 49 (1-2), 37-60

Albertazzi, D., Giovannini, A. and Seddone, A., 2018. 'No regionalism please, we are Leghisti!' The transformation of the Italian Lega Nord under the leadership of Matteo Salvini', Regional \& Federal Studies, 28 (5), 645-671

Atwood, M., 1986. The Handmaid's Tale. New York: HMHCO

Avanza, M., 2010. The Northern League and its 'innocuous' xenophobia. In A. Mammone, and GV. Veltri. eds. Italy today: The Sick Man of Europe Routledge, pp.131-142

Barcella, P., 2018. Percorsi leghisti. Dall'antimeridionalismo alla xenofobia. Meridiana, 91, 95-119

Bartlett, J., 2014. Populism, social media and democratic strain. In CN. Sandelind ed., European Populism and Winning the Immigration Debate, Falun: ScandBook, 99-114

Berlant, L., 2011. Cruel Optimism. Durham. NC: Duke University Press 
Betz, H-G., 1994. Radical Right-Wing Populism in Western Europe, New York: St. Martins Press

Bjønness, J., 2012. Between emotional Politics and Biased Practices - Prostitution Policies, Social Work, and Women selling Sexual Services in Denmark. Sexuality Research and Social Policy, 9 (3), 192-212

Bolognesi, M. and Ghaffaryans, S., 2015. The concept of power: A cross-linguistic and crosscultural study. In E. Nash, N.C. Brown, and L. Bracci, eds., Intercultural Horizons. Newcastle: Cambridge Scholars Publishing

Bobba, G., 2019. Social media populism: features and 'likeability' of Lega Nord communication on Facebook'. European Political Science. 18 (1), 11-23

Boiocchi, S., 2002. In Aiuto della Famiglia Contro la Prostituzione. La Padania, $6^{\text {th }}$ January.

Brown, W., 2006. Regulating Aversion. Princeton: Princeton University Press

Caiani, M. and Della Porta, D., 2011. The elitist populism of the extreme right: a frame analysis of extreme right-wing discourses in Italy and Germany. Acta Politica, 46, 180-202

Caneva, E., 2014., Intolerant Policies and Discourses in Northern Italian Cities. Journal of Immigrant \& Refugee Studies, 12 (4), 383-400.

Catanzaro, R., 2018. After and Beyond Amoral Familism: The Impact of the Economic Crisis on Social Capital Italian-style. South European Society and Politics, 23 (1),47-62,

Crowhurst, I., 2007. Socio-political and legal representations of migrant women sex labourers. In S. van Walsum and T. Spijkerboer eds., Women and immigration law in Europe. New variations on feminist themes, Abingdon: Routledge-Cavendish

Crowhurst, I., 2012. Caught in the victim/criminal paradigm: female migrant prostitution in contemporary Italy. Modern Italy, 17 (4), 493-506

Crowhurst, I., 2017. Troubling unknowns and certainties in prostitution policy claimsmaking'. In M. Spanger and ML Skilbrei, eds., Prostitution Research in Context: Methodology, Representation and Power. Abingdon: Routledge. 47-64

Crowhurst, I., 2019. The ambiguous taxation of prostitution: the role of fiscal arrangements in hindering the sexual and economic citizenship of sex workers. Sexuality Research and Social Policy, 16 (2), 166-178

Crowhurst, I., Tetaì, P., Di Feliciantonio, C., and Garofalo-Geymonat, G., 2017. Italy. In SO. Jahnsen and H. Wagenaar eds., Assessing Prostitution Policies in Europe. Abingdon: Routledge.

Danna, D., 2004., Italy: The never-ending debate. In J. Outshoorn ed., The Politics of Prostitution. Cambridge: Cambridge University Press. 165-184 
D'Aoust, AM., 2014. Ties that bind? Engaging emotions, governmentality and neoliberalism: introduction to the special issue. Global Society, 28 (3), 267-276

Demertziz, N., 2006. Emotions and populism. In P. Clarke, S. Hoggett and S. Thompson eds., Emotions, Politics and Society, Basingstoke: Palgrave Macmillan. 103-122

Douglas, M., 1966. Purity and Danger. Abingdon: Routledge

Duggan, L., 2003. The Twilight of Equality?: Neoliberalism, Cultural Politics, and the Attack on Democracy. Boston: Beacon Press

Fremeaux, I., and Albertazzi, N., 2002. Discursive Strategies around 'Community' in Political Propaganda: The Case of Lega Nord. National Identities, 4 (2), 145-160

Gibson, M., 1999. Prostitution and the State in Italy. 1860-1915. Columbus: Ohio State University Press.

Hameleers, M., Bos, L., and de Vreese, CH., 2017. 'They did it': the effects of emotionalised blame attribution in populist communication'. Communication Research, 44 (6), 870-900

Heaney, J., 2011. Emotions and power: reconciling conceptual twins. Journal of political power, 4 (2), 259-277

Heaney J., 2013. Emotions and power: a bifocal prescription to cure theoretical myopia. Journal of Political Power, 6 (3), 355-362

Hunter, S., 2014. Power, Politics and the Emotions: Impossible Governance? London: Routledge

Irvine, J., 2008. Transient Feelings: Sex Panics and the Politics of Emotions. GLQ: A Journal of Lesbian and Gay Studies, 14 (1), 1-40

Jagers, J. and Walgrave, S., 2007. Populism and political communication style: an empirical study of political parties' discourse in Belgium'. European Journal of Political Research, 46 (3), 319-345

Johnson, C., 2010. The politics of affective citizenship: from Blair to Obama, Citizenship Studies, 14 (5), 495-509

Jupp, E., Pykett, J., \& Smith, F., 2017. Emotional States: Sites and Spaces of Affective Governance. London: Routledge

Kriesi, H., 2014. The populist Challenge, West European Politics, 37(2), 361-378

Lega Nord., 2018. Scola Piemonte, Simonetti (ln): vergogna teoria gender, pronti denunce. Available from : https://www.leganord.org/notizie/le-news/14501-scuola-piemontesimonetti-ln-vergogna-teoria-gender-pronti-a-denunce [Accessed 18 July 2019]. 
Lega Nord. 2014a. Abrogazione della Legge Merlin. Available from:

https://www.leganord.org/phocadownload/ilmovimento/eventi/referendum2014/Referendum \%20Legge\%20Merlin.pdf [Accessed 18 July 2019].

Lega Nord. 2014b. Tasse, salute, legalita' anche in materia di PROSTITUZIONE. $L a$ Padania. Available from:

https://leganord.org/phocadownload/ilmovimento/eventi/referendum2014/SpecialelaPadania Referendum/1003_PAD2_02_C_S_R1.pdf [Accessed 18 July 2019].

Lega Nord. 2012. Scheda posizione politica: prostituzione. Available from: https://www.leganord.org/phocadownload/leidee/2012/giustizia-sicurezzaimmigrazione/Sicurezza/Prostituzione.pdf [Accessed 18 July 2019].

Lega Nord. 2002a. La battaglia della Lega Nord control la prostituzione di strada, la pedofilia e la pornografia. Segreteria Politica Federale, Lega Nord Padania

Lega Nord. 2002b. Cronistoria della Lega Nord. 2002. Available from: https://www.leganord.org/phocadownload/ilmovimento/storia_ln/07_lega_nord_storia2002.p df [Accessed 18 July 2019].

Nagel, J., 2003. Race, Ethnicity, and Sexuality: Intimate Intersections, Forbidden Frontiers. Oxford: Oxford University Press.

Newman, J., 2017. Rationality, responsibility and rage: the contested politics of emotion governance. In E. Jupp, J. Pykett and FM. Smith eds., Emotional States: Sites and Spaces of Affective Governance. London: Routledge

Pykett, J., Jupp, E. \& Smith, FM., 2017. Introduction: governing with feelings. In E. Jupp, J. Pykett and FM. Smith eds., Emotional States: Sites and Spaces of Affective Governance. London: Routledge

Rico, G., Guinjoan, M. and Anduiza, E., 2017. The Emotional Underpinnings of Populism: How Anger and Fear Affect Populist Attitudes. Swiss Political Science Review, 23 (4), 444461

Rubin, G. 1984. Thinking sex: notes for a radical theory of the politics of sexuality. In C.S. Vance ed., Pleasure and Danger. London: Routledge, 267-319

Saitta, P. and Piasecka, A. 2006. The Hidden Normative Process Behind the Construction of European Migration Policies. Sociologia del diritto, 3, 75-96

Samela, M. and von Scheve, C., 2017. Emotional roots of right-wing political populism. Social Science Information. 56 (4), 567-595

Savoini, G., 2002. Gazebo in Piazza Contro la Prostituzione e Pedofilia. La Padania, $23^{\text {rd }}$ May.

Scoular, J., 2015. The subject of prostitution. Abingdon: Routledge 
Scrinzi, F., 2017. Caring for the elderly in the family or in the nation? Gender, women and migrant care labour in the Lega Nord. West European Politics, 40 (4), 869-886

Thompson, S. and Hoggett, P., 2012 The affective turn in contemporary political studies. In S. Thompson, S. and P. Hoggett, eds., Politics and the Emotions. London: Continuum.

Vasilopoulou, S., D. Halikiopoulou and Exadaktylos, T., 2014. Greece in Crisis: Austerity, Populism and the Politics of Blame. Journal of Common Market Studies 52 (2), 388-402.

Wagenaar, H., 2018. Policy as Practice: Explaining Persistent Patterns in Prostitution Policy. The Howard Journal. 57 (3), 379-400

Wagenaar, H. and Altink, S., 2012. Prostitution as morality politics or why it is exceedingly difficult to design and sustain effective prostitution policy. Sexuality Research and Social Policy, 9 (3), 279-97.

Wagenaar, H., Amesberger, H. and Altink, S., 2017. Designing Prostitution Policy: Intention and Reality in the Sex Trade, Bristol: Policy Press.

\section{Walsh, C., 2018. Racial Taxation. Chapel Hill: University North Carolina Press}

\footnotetext{
${ }^{1}$ Law 75 of 1958, the so-called Merlin Law, named after Senator Lina Merlin who proposed it, is Italy's main piece of legislation specifically addressing prostitution. It abolished the regulationist system that had been in place in the country since the 1860 s. It does not criminalize prostitution but bans brothels and criminalizes most prostitution-related activities, including soliciting, aiding and abetting and profiting from the prostitution of others (Crowhurst, Testai', Di Feliciantonio, Garofalo Geymonat, 2017).

${ }^{2}$ The terms were searched for in Italian, thus: 'prostituzione', 'Merlin', 'prostituta' and 'prostitute', and sex work in English (which was found in one tweet only).

${ }^{3}$ All documents originally in Italian have been translated by the author.

${ }^{4}$ Capitalized letter in the original in this and other cited tweets.

${ }^{5}$ The collection of signatures pertained to the repeal of five different laws, each addressing a distinct issue.

${ }^{6}$ This term is widely used in Italy. It originally indicated anyone who is not from the European Union, but soon became adopted with a derogatory meaning to characterize unwanted 'foreigners' who do not belong (Bolognesi and Ghaffaryans 2015).

${ }^{7}$ Italy was struck hard by the 2007 global financial crisis as a result of which it was hit by a number of recessions. To this day the country's economy remains very weak, contributing to low productivity and high unemployment (Catanzaro 2018).

${ }^{8}$ The tweets mentioned here were posted before the Northern League entered in the coalition government in 2018.

${ }^{9}$ This is the only tweet on the matter posted in English language. It is also the only one where Matteo Salvini uses the term 'sex worker'; when writing in Italian he uses the still more broadly adopted, term prostitute/s (gendered female).
} 